\title{
Solving Transmission Expansion Planning Problem by Enactmenting Differential Examination
}

\author{
Karunya Rajha G S, Shilaja C
}

\begin{abstract}
At present the power systems involve extensive and composite unified transmission structures, for substantial issues. It is an extensive, multifaceted and nonlinear problem with multiple solutions to be estimated upsurges with respect to the size of the system. In this decade, differential evolution (DE) algorithm have been employed by several researchers as it is awfully active in resolving optimization problems. In this study, TEP problem is considered in static arrangement. Moreover, one of the cases of static TEP problem has been studied as without generation resizing. $D E$ has attained results with decent exactness, easiness and acceptable execution time. The simulations have been executed using MATLAB.
\end{abstract}

Keywords : AC power flow, Differential Evolution, Garver's 6 bus system and Transmission Expansion Planning.

\section{INTRODUCTION}

Electricity is a vital energy as it is transferred easily at good efficacy at least cost. At present the real-world power systems are extensive and more complex unified transmission systems. The power system is split up into four segments such as generation, transmission, distribution and load [1-3]. Transmission system aims to transmit power to different sites to the distribution structures that finally deliver to the load. Transmission lines that interrelated adjacent sources allow cost-effective power delivery athwart areas during usual situations along with the transmission of power amid areas during crisis. Over the previous years, capacity of power to be transmitted from plants to main load are rising intensely. In this study, transmission systems are investigated for optimizing TEP problem [2]. Transmission lines are primarily erected to connect distant power plants to load areas, therefore permitting power plants to be sited in areas that are cheap and ecologically fit. By way of systems developed, interconnected networks of transmission lines have arose, offering substitute tracks to transmit power from plants to the loads to increase the consistency. In areas where plants or loads are unfair, production [5]. Surplus transmission capability is necessary when there is a requirement to connect low-priced generation to satisfy rising load or improve system reliability.

Revised Manuscript Received on December 15, 2019.

* Correspondence Author

Karunya Rajha G S, Dept of EEE, Kalasalingam Academy of Research and Education, Tamilnadu, India. Email: kaaru91@ gmail.com

Shilaja C*, Dept of EEE, Kalasalingam Academy of Research and Education, Krishnankoil, India. Email: shilaja.research@gmail.com

\section{TEP PROBLEM}

In general, TEP faces a nonlinear difficulty by DC power flow equations, with great intricacy, particularly for extensive practical transmission networks. Numerous replacements to the DC model for example the transmission, cross and disjunctive prototypes.

The aim of TEP problem is to minimize capital cost while fulfilling subjected constraints. The standard DC power flow model is employed to resolve TEP problem. It is expressed as follows.

$$
\min v=\sum_{(i, j) \in w} c_{i j} n_{i j}
$$

where $\mathrm{v}$, cij and nij denote, transmission capital cost, cost of a nominee route for expansion to the branch $i-j$ and the no. of routes included to the branch $\mathrm{i}-\mathrm{j}$.

\section{Problem constraints}

Equ (1) signifies connected transmission lines, with number of limitations. These constraints must be encompassed into mathematical formulations to confirm that the ideal result fulfils TEP desires. They are defined as follows

\section{1) Kirchoff's current law}

TEP optimization is inhibited by Kirchhoff's current law, which necessitates that the overall power running into a nodule must be equivalent to the overall power coming out of the nodule:

$$
A^{o} F_{p}^{o}-P_{p}+D_{p}=0 \quad \forall p=1, \ldots, n p
$$

where $A^{o}$ is the nodule-branch incidence matrix of the system, $F_{p}^{o}$ is the vector of transmission line transfers during load.

\section{2) Kirchoff's Voltage Law}

It infers the actual constraint for relays runs and additions

$F_{p}^{o}=H^{o}\left(P_{p}-D_{p}\right) \quad \forall p=1, \ldots, n p$

\section{3) Transmission line flows}

The thermal limitations on the line which should be fulfilled:

$$
-T \leq F_{p}^{o} \leq T \quad \forall p=1, \ldots, n p
$$

Equ (2) to (4) have been formulated by DC power flow equations ignoring losses. 


\section{Solving Transmission Expansion Planning Problem by Enactmenting Differential Examination}

\section{4) Output of the generators}

The optimization should consider the bounds on the production by the generators.

$$
P^{\min } \leq P_{p} \leq P^{\max } \quad \forall p=1, \ldots, n p
$$

where, $P^{\min }$ is the vector of least nodal generations and $P^{\max }$ is the vector of extreme nodal generations.

\section{DIFFERENTIAL EVOLUTION ALGORITHM}

Price and Storn introduced DE as a population-based stochastic direct search technique. A detailed description about DE has been provided in [9].

\section{A. Implentation of DE to TEP}

1) Primal Static TEP

$$
F_{s}=\frac{1}{O_{s}(x)+w_{1} p_{1}(x)+w_{2} p_{2}(x)}
$$

$\mathrm{Fs}(\mathrm{X})$ is the fitness function

$\mathrm{Os}(\mathrm{X})$ is the objective function

$\mathrm{P} 1(\mathrm{X})$ is the equality constraint

$\mathrm{P} 2(\mathrm{X})$ is the inequality constraint

$\mathrm{X}$ is the separate vector of decision variables

Penalty weighting factor is set as 0.5 .

The objective and penalty formulations are defined as follows.

$$
\begin{aligned}
& O_{s}=V(X)=\sum_{(i j) \in \Omega} c_{i j} n_{i j} \\
& P_{1}(X)=\sum_{k=1}^{n b}\left|d_{k B_{k}} \theta_{k k}\right| \\
& P_{2}(X)=\sum_{l=1}^{n c} \mu_{1}
\end{aligned}
$$

nb and nc signify the no. of buses in the system and the no. of inequality constraints.

\section{RESULT AND DISCUSSION}

The simulation has been made for TEP by developing program on MATLAB R2018a and MATPOWER 4.1 software.. It consists of 5 buses in which 3 buses are load bus and 2 buses are generator bus. The generator data, load and branch data are given in appendix. Figure 1 shows power flow result for existing network and Figure 2 shows network with predicted demands and generating plants. The existing power system with future loads and new generation is shown in Figure 2. Each load is assumed to be four times the present values. Two $120 \mathrm{MW}$ units have been included at bus 3 and new bus 6 with three new units each have capacity of 120 MW,240 MW, 240 MW respectively has been established.



Figure 1: Generation - Transmission system

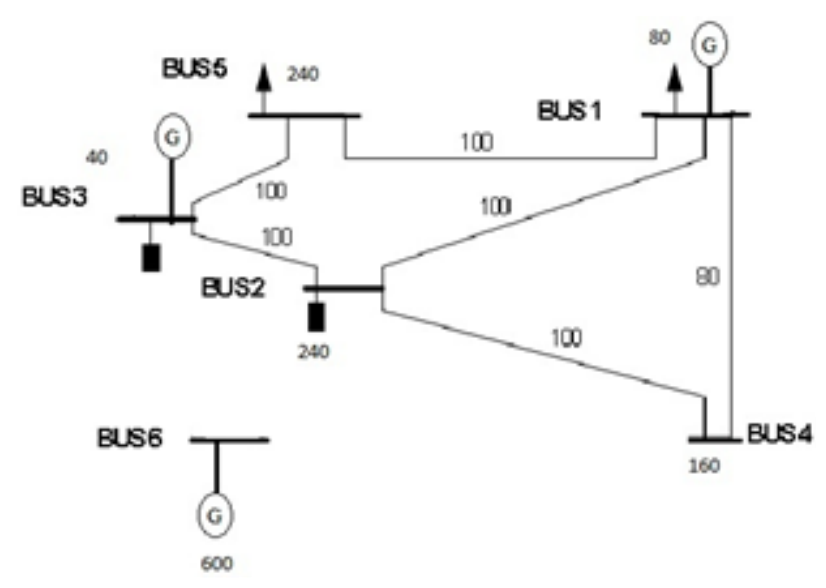

Figure 2: Predicted Network loads with generating plants

Table 1: NETWORK POWER FLOW RESULT

\begin{tabular}{|l|l|l|l|l|l|l|l|l|}
\hline $\begin{array}{c}\text { Branch } \\
\#\end{array}$ & $\begin{array}{c}\text { From } \\
\text { Bus }\end{array}$ & $\begin{array}{c}\text { To } \\
\text { Bus }\end{array}$ & $\begin{array}{c}\text { From Bus } \\
\text { P(MW) }\end{array}$ & $\begin{array}{c}\text { Injection } \\
\text { Q(MVAr) }\end{array}$ & $\begin{array}{c}\text { To Bus } \\
\text { P(MW) }\end{array}$ & $\begin{array}{c}\text { Injection } \\
\text { Q(MVAr) }\end{array}$ & \multicolumn{2}{c|}{$\begin{array}{c}\text { LOSS (MW) } \\
\text { Q(MVAr) }\end{array}$} \\
\hline 1 & 1 & 2 & 16.24 & 1.38 & -16.00 & -0.41 & 0.241 & 0.96 \\
\hline 2 & 1 & 4 & 22.99 & 2.65 & -22.26 & 0.26 & 0.729 & 2.92 \\
\hline 3 & 1 & 5 & 14.90 & -0.21 & -14.80 & 0.61 & 0.101 & 0.40 \\
\hline 4 & 2 & 3 & -62.05 & -1.08 & 63.86 & 8.33 & 1.811 & 7.25 \\
\hline 5 & 2 & 4 & 18.04 & 1.50 & -17.74 & -0.26 & 0.308 & 1.23 \\
\hline 6 & 3 & 5 & 46.14 & 4.36 & -45.20 & -0.61 & 0.938 & 3.75 \\
\hline
\end{tabular}


International Journal of Innovative Technology and Exploring Engineering (IJITEE)

ISSN: 2278-3075, Volume-9 Issue-2S2, December 2019

Table 2: NETWORK WITH FUTURE LOADS AND GENERATING UNITS POWER FLOW RESULT

\begin{tabular}{|c|c|c|c|c|c|c|c|c|}
\hline \multirow{2}{*}{$\begin{array}{c}\text { Branch } \\
\#\end{array}$} & \multirow{2}{*}{$\begin{array}{c}\text { From } \\
\text { Bus }\end{array}$} & \multirow{2}{*}{$\begin{array}{c}\text { To } \\
\text { Bus }\end{array}$} & \multirow{2}{*}{$\begin{array}{c}\text { From Bus } \\
\text { P(MW) }\end{array}$} & \multirow{2}{*}{$\begin{array}{l}\text { Injection } \\
\text { Q(MVAr) }\end{array}$} & \multirow{2}{*}{$\begin{array}{l}\text { To Bus } \\
\text { P(MW) }\end{array}$} & \multirow{2}{*}{$\begin{array}{l}\text { Injection } \\
\text { Q(MVAr) }\end{array}$} & \multicolumn{2}{|c|}{ LOSS } \\
\hline & & & & & & & $\mathbf{P}(\mathbf{M W})$ & Q(MVAr) \\
\hline 1 & 1 & 2 & 144.94 & -11.99 & -125.76 & 88.73 & 19.185 & 76.74 \\
\hline 2 & 1 & 4 & 107.07 & -35.78 & -89.73 & 105.14 & 17.339 & 69.36 \\
\hline 3 & 1 & 5 & 216.93 & 34.29 & -195.05 & 53.21 & 21.875 & 87.50 \\
\hline 4 & 2 & 3 & -81.86 & 50.90 & 85.62 & -35.85 & 3.763 & 15.05 \\
\hline 5 & 2 & 4 & -8.09 & -46.42 & 9.88 & 53.61 & 1.798 & 7.19 \\
\hline 6 & 3 & 5 & 37.96 & 46.49 & -36.38 & -40.20 & 1.573 & 6.29 \\
\hline & & & Total & 65.53 & 262. & & & \\
\hline
\end{tabular}

Table 3: SYSTEM EXPANSION USING DE

\begin{tabular}{|l|l|l|l|}
\hline S.NO & $\begin{array}{c}\text { NEW LINE } \\
\text { ADDED }\end{array}$ & $\begin{array}{c}\text { NO OF } \\
\text { PARALLEL } \\
\text { PATH }\end{array}$ & $\begin{array}{c}\text { COST } \times \mathbf{1 0}^{3} \\
\text { (US\$) }\end{array}$ \\
\hline 1 & $2-6$ & 2 & 60 \\
\hline 2 & $3-5$ & 2 & 40 \\
\hline 3 & $4-6$ & 3 & 90 \\
\hline 4 & $5-6$ & 1 & 61 \\
\hline \multicolumn{2}{|l|}{ TOTAL COST } & 251 \\
\hline
\end{tabular}

Table 4: SYSTEM EXPANSION USING POWER FLOW RESULTS

\begin{tabular}{|l|l|l|l|l|l|l|l|l|}
\hline $\begin{array}{c}\text { Branch } \\
\#\end{array}$ & $\begin{array}{c}\text { From } \\
\text { Bus }\end{array}$ & $\begin{array}{c}\text { To } \\
\text { Bus }\end{array}$ & $\begin{array}{c}\text { From } \\
\text { Bus } \\
\text { P(MW) }\end{array}$ & $\begin{array}{c}\text { Injection } \\
\text { Q(MVAr) }\end{array}$ & $\begin{array}{c}\text { To Bus } \\
\text { P(MW) }\end{array}$ & $\begin{array}{c}\text { Injection } \\
\text { Q(MVAr) }\end{array}$ & \multicolumn{2}{|l|}{ P(MW) } \\
Q(MVAr) \\
\hline 1
\end{tabular}

\section{A. Network with wind loads and generating units} power flow results

The existing power system with future loads and new generation is shown in Figure 3. Each load is assumed to be four times the present values. Two $120 \mathrm{MW}$ units have been included at bus 3 and new bus 6 with three new units each have capacity of $120 \mathrm{MW}, 240 \mathrm{MW}, 240 \mathrm{MW}$ respectively has been established. Figure 3 shows power flow result for existing network future load and generation. Figure 3 infers that it satisfies power flow equation but the first three lines are overloaded to alleviate this overload the system to be expanded.

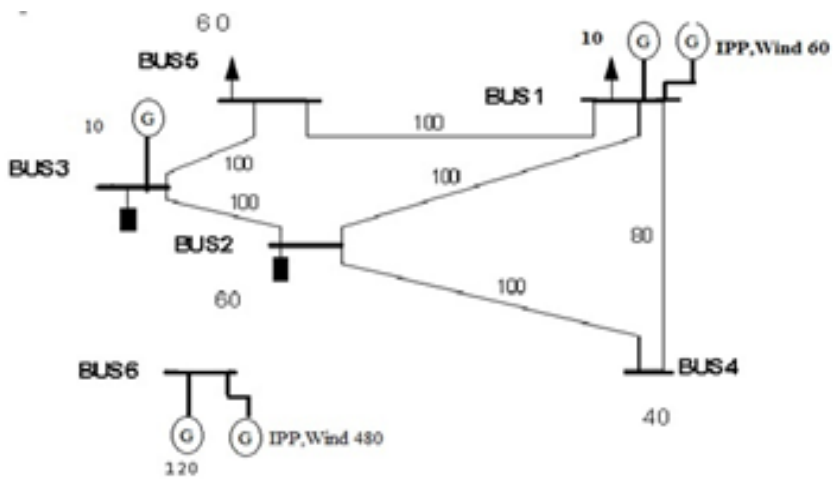

Fig. 3 Power flow result for existing network future load and generation 
Table 5: SYSTEM EXPANSION WITH WIND USING DE

\begin{tabular}{|l|l|l|l|}
\hline S.NO & $\begin{array}{c}\text { NEW } \\
\text { LINE } \\
\text { ADDED }\end{array}$ & $\begin{array}{c}\text { NO OF } \\
\text { PARALLEL } \\
\text { PATH }\end{array}$ & $\begin{array}{c}\text { COST } \times \mathbf{1 0}^{\mathbf{3}} \\
(\mathbf{U S \$} \mathbf{)}\end{array}$ \\
\hline 1 & $2-6$ & 2 & 80 \\
\hline 2 & $3-5$ & 2 & 60 \\
\hline 3 & $4-6$ & 3 & 100 \\
\hline 4 & $5-6$ & 1 & 81 \\
\hline \multicolumn{2}{|l}{} & 321 \\
\hline
\end{tabular}

Table 6: NETWORK WITH FUTURE LOADS AND GENERATING UNITS POWER FLOW RESULT

\begin{tabular}{|l|l|l|l|l|l|l|l|l|}
\hline $\begin{array}{c}\text { Branch } \\
\#\end{array}$ & $\begin{array}{c}\text { From } \\
\text { Bus }\end{array}$ & $\begin{array}{c}\text { To } \\
\text { Bus }\end{array}$ & $\begin{array}{c}\text { From } \\
\text { Bus } \\
\text { P(MW) }\end{array}$ & $\begin{array}{c}\text { Injection } \\
\text { Q(MVAr) }\end{array}$ & $\begin{array}{c}\text { To Bus } \\
\text { P(MW) }\end{array}$ & $\begin{array}{c}\text { Injection } \\
\text { Q(MVAr) }\end{array}$ & \multicolumn{2}{|l|}{ P(MW) } \\
Q(MVAr) \\
\hline 1 & 1 & 2 & 144.94 & -11.99 & -125.76 & 88.73 & 19.185 & 96.74 \\
\hline 2 & 1 & 4 & 107.07 & -35.78 & -89.73 & 105.14 & 17.339 & 100.36 \\
\hline 3 & 1 & 5 & 216.93 & 34.29 & -195.05 & 53.21 & 21.875 & 97.50 \\
\hline 4 & 2 & 3 & -81.86 & 50.90 & 85.62 & -35.85 & 3.763 & 15.05 \\
\hline 5 & 2 & 4 & -8.09 & -46.42 & 9.88 & 53.61 & 1.798 & 17.19 \\
\hline 6 & 3 & 5 & 37.96 & 46.49 & -36.38 & -40.20 & 1.573 & 20.29 \\
\hline
\end{tabular}

Table 7: NETWORK WITH FUTURE LOADS AND GENERATING UNITS POWER FLOW RESULT

\begin{tabular}{|l|l|l|l|l|l|l|l|l|}
\hline $\begin{array}{c}\text { Branch } \\
\#\end{array}$ & $\begin{array}{c}\text { From } \\
\text { Bus }\end{array}$ & $\begin{array}{c}\text { To } \\
\text { Bus }\end{array}$ & $\begin{array}{c}\text { From } \\
\text { Bus } \\
\text { P(MW) }\end{array}$ & $\begin{array}{c}\text { Injection } \\
\text { Q(MVAr) }\end{array}$ & $\begin{array}{c}\text { To Bus } \\
\text { P(MW) }\end{array}$ & \multicolumn{1}{|c|}{$\begin{array}{c}\text { Injection } \\
\text { Q(MVAr) }\end{array}$} & \multicolumn{2}{c|}{ P(MW) } \\
Q(MVAr) \\
1 \\
\hline 2 & 1 & 2 & -2.79 & 15.54 & 3.02 & -14.63 & 0.226 & 0.90 \\
\hline 3 & 1 & 4 & -22.99 & 15.72 & 24.05 & -11.50 & 1.056 & 4.22 \\
\hline 4 & 1 & 5 & 43.02 & 15.72 & -42.17 & 0.98 & 0.842 & 6.37 \\
\hline 5 & 2 & 3 & 6.58 & 2.38 & -5.78 & 42.47 & 0.802 & 6.21 \\
\hline 6 & 2 & 4 & -30.19 & -39.26 & 31.16 & -2.97 & 0.970 & 3.88 \\
\hline 7 & 2 & 6 & -109.70 & 6.85 & 119.90 & 14.72 & 20.196 & 38.24 \\
\hline 8 & 2 & 6 & -109.70 & 23.52 & 119.90 & 14.72 & 10.196 & 38.24 \\
\hline 9 & 3 & 5 & 43.59 & 23.52 & -42.69 & -9.36 & 0.903 & 7.61 \\
\hline 10 & 3 & 5 & 43.59 & 12.97 & -42.69 & -9.36 & 0.903 & 3.61 \\
\hline 11 & 3 & 5 & 43.59 & 12.97 & -42.69 & -9.36 & 0.903 & 3.61 \\
\hline 12 & 4 & 6 & -71.74 & 4.82 & 75.83 & 10.54 & 10.096 & 20.36 \\
\hline 13 & 4 & 6 & -71.74 & 4.82 & 75.83 & 10.54 & 4.096 & 20.36 \\
\hline 14 & 5 & 6 & -71.74 & 4.82 & 75.83 & 10.54 & 4.096 & 15.36 \\
\hline
\end{tabular}

The attained results of Graver's system using proposed approach are presented in Table VII. The discussion regarding the results have been provided as follows: Here, the best result of the static TEP problem was obtained by $\mathrm{DE}$. The capital cost will be $\mathrm{v}=\$ 251,000$ with the following topology: $n 2-6=2, n 3-5=2$ and n4-6 = 3, n5-6 = 1 From the results it is identified that all overloaded are alleviated and new lines power flow limit are also within the limit.

\section{CONCLUSION}

Least cost TEP is a foremost defy in power system optimization by way of its chief aim is to attain the ideal expansion plan that satisfies the desires while providing cost-effective investment. In this study, TEP problem has been solved in static form. Moreover, a case of static TEP problem, without plant resizing, have also been studied. The proposed DE algorithm has attained outcomes with excellent accuracy, easy implementation and acceptable execution time. The investigations have been carried out in the mathematical programming environment of MATLAB. The outcomes have demonstrated the excellent concession, the efficacy and computational efforts of DE while solving TEP

\section{REFERENCES}

1. N. Alguacil, A. L. Motto and A. J. Conejo, "Transmission expansion planning: A mixed-integer LP approach,” IEEE Trans. Power Syst., vol. 18, no. 3, pp. 1070-1077, Aug. 2003.

2. R.Romero, C.Rocha, J.R S. Mantovani and I. G. Sanchez, "Constructive heuristic algorithm for the DC model in network transmission expansion planning," IEE Proc. Gener. Transm. Distrib., vol. 152, no. 2, pp. 277-282, Mar. 2005.

3. T. Sum-Im, G. A. Taylor, M. R. Irving and Y. H. Song, "Differential evolution algorithm for static and multistage transmission expansion planning," IET Proc. Gener. Transm. Distrib., (Accepted 2009).

4. R. Romero, A. Monticelli, A. Garcia and S. Haffner, "Test systems and mathematical models for transmission network expansion planning," IEE Proc. Gener. Transm. Distrib., vol. 149, no.1, pp. 27-36, Jan. 2002

5. L. L. Garver, "Transmission network estimation using linear programming," IEEE Trans. Power App. Syst., vol. PAS-89, no.7, pp.1688-1697, Sep./Oct. 1970.

6. S. Haffner, A. Monticelli, A. Garcia, J. Mantovani and R. Romero, "Branch and bound algorithm for transmission system expansion planning using transportation model," IEE Proc. Gener. Transm. Distrib., vol. 147, no.3, pp. 149-156, May 2000.

7. S. Haffner, A. Monticelli, A. Garcia and R. Romero, "Specialised branch and bound algorithm for transmission network expansion planning," IEE Proc. Gener. Transm. Distrib., vol. 148, no. 5, pp. 482-488, Sep. 2001. 
8. T. Sum-Im, G. A. Taylor, M. R. Irving, M. R. and Y. H. Song, "A comparative study of state-of-the-art transmission expansion planning tools," in Proc. the 41st International Universities Power Engineering Conference (UPEC 2006), Newcastle upon Tyne, United Kingdom, pp. 267-271, 6th-8th Sep. 2006.

9. A.Bhuvanesh, S.T.Jaya Christa, S.Kannan, M.Karuppasamypandiyan, "Application of optimization algorithms to generation expansion planning problem", Journal of Intelligent \& Fuzzy Systems, vol. 35, no. 2, pp. 1387-1398, 2018.

\section{AUTHORS PROFILE}

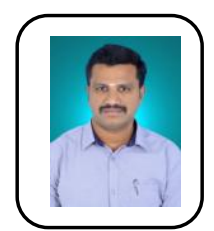

Karunya Rajha.G.S doing his Ph.D. in Electrical \& Electronics Engineering from Kalasalingam Academy of Research and Education, Krishnankovil. His M.E. in power Electronics \& Drives from Anna University in 2016 and his B.E. in Electrical and Electronics Engineering from Anna University in 2013.His research interests include Generation Expansion Planning. Power System.

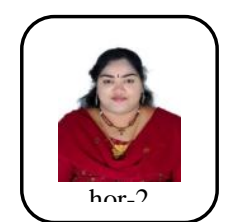

Dr.C.Shilaja is a Research Faculty in Department of Electrical and Electronics Engineering in Kalasalingam Academy of Research and Education. Now currently pursuing Post-Doctoral Fellowship from Kalasalingam Academy of Research and Education from 2018, received her Ph.D. in Power System Electrical \& Electronics Engineering from VIT University Vellore in 2018, her M.E. in Power Electronics \& Industrial Drives from Sathyabama University in 2010 and her MBA in Human Resources from Alagappa University karaikudi in 2007. Then her B.E. in Electrical and Electronics Engineering from Madras University in 2003. Her Research interests includes power system optimization, Renewable Energy, Optimal scheduling \& Power system planning. She has published 18 International Reputed Journals and 4 International conferences in these areas. 